\title{
Nursing diagnoses and interventions in children submitted to cochlear implantation*
}

\author{
Diagnósticos e intervenções de enfermagem em crianças submetidas a implante coclear \\ Diagnósticos e intervenciones de enfermería en niños sometidos a implante coclear
}

Patrícia Juliana Santos Pereira ${ }^{1}$, Natália Fernanda Higa de Souza ${ }^{1}$, Raissa Janine de Almeida ${ }^{1}$, Daiane Cabrera Menezes ${ }^{1}$, Gesiane Cristina Bom², Armando dos Santos Trettene ${ }^{2,3}$

How to cite this article:

Pereira PJS, Souza NFH, Almeida RJ, Menezes DC, Bom GC, Trettene AS. Nursing diagnoses and interventions in children submitted to cochlear implantation. Rev Esc Enferm USP. 2017;51:e03238. DOI: http://dx.doi.org/10.1590/S1980-220X2016045203238

\footnotetext{
* Extracted from the final course project of "Diagnósticos e intervenções de enfermagem em crianças submetidas a implante coclear referente ao pós-operatório imediato", Programa de Residência Multiprofissional em Saúde, Síndromes e Anomalias Craniofaciais, Hospital de Reabilitação de Anomalias Craniofaciais, Universidade de São Paulo, 2016.

${ }^{1}$ Universidade de São Paulo, Hospital de Reabilitação de Anomalias Craniofaciais, Programa de Residência Multiprofissional em Saúde, Síndromes e Anomalias Craniofaciais, Bauru, SP, Brazil.

${ }^{2}$ Universidade de São Paulo, Hospital de Reabilitação de Anomalias Craniofaciais, Programa de Pós-Graduação em Ciências da Reabilitação, Bauru, SP, Brazil.

${ }^{3}$ Universidade Paulista, Departamento de Enfermagem, Campus de Bauru, Bauru, SP, Brazil.
}

\begin{abstract}
Objective: Identifying the main nursing diagnoses and interventions in children submitted to cochlear implant in the immediate postoperative period. Method: A crosssectional study conducted between February and April 2016, considering nursing history (anamnesis and physical examination) and nursing diagnoses (NANDA International) with their respective interventions (Nursing Intervention Classification NIC). Descriptive statistical analysis was used to construct the results. Results: A total of 19 children participated in this study. The main nursing diagnoses listed were: impaired verbal communication, impaired skin integrity, risk for infection, risk for falls, and risk for bleeding $(n=19 ; 100 \%)$. Regarding the nursing interventions, the following prevailed: Improvement in communication: auditory deficit, Skin surveillance, Protection against infection, Prevention of falls and Precautions against bleeding ( $n=19 ; 100 \%)$. Conclusion: Nursing diagnoses and interventions related to the cochlear implant postoperative period were related to communication, bleeding control, surgical wound care, infection prevention, comfort and well-being.
\end{abstract}

\section{DESCRIPTORS}

Pediatric Nursing; Cochlear Implantation; Hearing Loss; Nursing Process; Nursing Diagnosis.

Corresponding author:

Armando dos Santos Trettene

Rua Silvio Marchione, 3-20

CEP 17012-900 - Bauru, SP, Brazil

armandotrettene@usp.br 


\section{INTRODUCTION}

Communication is an essential activity for life in society and is considered an important tool for integration, development and socialization ${ }^{(1)}$. Auditory deficiency (AD) is interpreted as a disturbance in the communication process, and it is indicated as one of the main etiological factors of language development and speech impairment ${ }^{(2)}$.

$\mathrm{AD}$ can compromise relationships with other people, lifestyle and academic-linguistic development, leading to social and emotional changes, including parents and caregivers of children with this deficiency ${ }^{(2-3)}$. It is considered a public health problem, especially in childhood due to its high prevalence ${ }^{(4)}$. In the Brazilian population, overall $\mathrm{AD}$ incidence is $5.10 \% \%^{(5)}$.

Although costly, technological advancement has enabled early and accurate diagnosis of AD, in addition to broadening treatment modalities. In this context, cochlear implant (CI) emerges as one of the available resources, being eligible and effective in treating people with a severe degree and/ or profound $\mathrm{AD}^{(6)}$.

The CI is a biocompatible and durable external electronic component located behind the ear, whose function is to capture, process and encode sound energy and send it to a receiver via radio frequency. It has a surgically implanted device composed of a bundle of electrodes inserted into the cochlea to electrically stimulate the fibers of the auditory nerve, performing the function of the damaged or absent auditory cells. A propagation of impulses to the auditory cortical area of the brain occurs with stimulation of the auditory nerve ${ }^{(7)}$.

Literature is scarce regarding the nurse's role in the area of auditory health, including treatment with CI. Nursing care begins in the preoperative phase through provision of guidelines and strengthening the decision-making process, extending to the intra and postoperative periods, including preparing caregivers regarding home care $^{(8)}$.

Several instruments have been proposed in order to systematize nursing care. Among them, the Nursing Process is an instrument of great importance to assist nursing professionals for organizing and systematizing the care to be provided to individuals including decision making and data management to actions and interventions to be performed. As it is an intellectual activity, it is possible to identify the specific needs of each patient, aiming for the best possible response for their treatment and/or rehabilitation ${ }^{(9)}$.

The Nursing Process is composed of the following steps: History (anamnesis and physical examination), Diagnosis, Prescription (nursing interventions), Evolution and Nursing Evaluation ${ }^{(9)}$. For the present study we have considered History and Nursing Diagnoses.

Nursing History is performed upon patient admission through an informal interview and physical examination. In turn, Nursing diagnosis is performed after analysis and history evaluation, patient's needs are defined by identifying their problems, thereby directing the nursing team to provide care $^{(9)}$. Nursing diagnoses are classified as real, of risk, wellbeing, syndrome and health promotion ${ }^{(10)}$.

In order to facilitate the nursing process and make it more uniform and representative, standardized language or taxonomies have been developed, including those related to diagnoses such as the NANDA - International Nursing Diagnostic Classification, and interventions such as NIC Nursing Interventions Classification, which presents interventions with their respective nursing activities specific to each nursing diagnosis ${ }^{(10-11)}$.

The benefits of the Nursing Process are diverse, both for the patients and for the nursing team, as well as the use of taxonomies. For the nursing team, they focus on professional qualification, and consequently appreciation, recognition, legal support and optimization of care, as well as serving as a research tool. For patients, they guarantee individualized care, and improve the relationship between professionals, patients and caregivers, resulting in qualified and humanized care ${ }^{(12)}$.

In this context, we asked: What are the Nursing Diagnoses and Interventions eligible for children submitted to cochlear implant, related to the immediate postoperative period?

The National Policy on Hearing Health Care is expanding in Brazilian health services, including the expansion of care to patients with $\mathrm{AD}$ who are eligible for $\mathrm{CI}$ treatment. In this context, studies that address Nursing Diagnoses and Interventions may collaborate to disseminate this specific knowledge, thus contributing to the effectiveness of the Nursing Process, humanization of care, quality of care, and patient safety. No studies were found with this approach in the consulted databases, emphasizing the importance of this investigation.

Therefore, the objective of this study was to identify the main nursing Diagnoses and Interventions in children submitted to cochlear implant in the immediate postoperative period.

\section{METHOD}

A descriptive, cross-sectional and quantitative study developed in a tertiary hospital located in the countryside of the state of São Paulo. This is an institution of national and international reference in caring for patients with craniofacial anomalies and related syndromes, which includes care for patients with AD. It is managed by the Universidade de São Paulo with resources from the Unified Health System and has activities in the areas of care, teaching and research. The offered care is multiprofessional and interdisciplinary.

The population was composed of children submitted to CI who were in the immediate postoperative period, which corresponded to the first 24 hours after the surgical procedure. Considering the monthly average of surgeries and the data collection period, the sample comprised 19 children. The inclusion criteria were: exclusively being in the immediate postoperative period of cochlear implant, not having any other clinical comorbidities and/or associated syndromes, and being between 1 and 5 years of age.

Data collection was performed through the Nursing History, which included anamnesis (physical and sociodemographic data collection of the child) and physical examination. The nursing Diagnoses were subsequently formalized from the data listed in the History using the NANDA 
- International taxonomy, version $2012-2014^{(10)}$. Finally, Nursing Interventions were identified from the listed nursing Diagnoses according to the taxonomy of the NIC in the 2016 version $^{(11)}$. The results were submitted to descriptive statistical analysis.

The research was initiated after approval of the Committee of Ethics in Research involving Human Beings of the Hospital through the opinion number 1.396.734 and CAAE 49455615.4.0000.5441. A Term of Commitment of the Responsible Researcher was formalized considering that data collection was carried out by consulting medical records, obeying the precepts of Resolution 466/2012.

\section{RESULTS}

A total of 19 children with a mean age of 3 years $( \pm$ 1.38) participated in the study. Males were the predominant gender $(n=11 ; 58 \%)$. Low socioeconomic classification also prevailed ( $\mathrm{n}=10 ; 53 \%)$.

The nursing Diagnoses listed in the present study were: Impaired verbal communication, impaired skin integrity, risk for infection, risk for falls, risk for bleeding ( $n=19,100 \%)$, impaired comfort $(n=8 ; 42 \%)$, nausea $(n=4 ; 21 \%)$, anxiety $(n=2 ; 10 \%)$ and acute pain $(n=1 ; 5 \%)($ Table 1$)$.

Table 1 - Nursing diagnoses of children in the immediate postoperative period of cochlear implantation - Bauru, SP, Brazil, 2016.

\begin{tabular}{lc}
\hline Nursing diagnoses & $\mathbf{n}(\%)$ \\
\hline Impaired verbal communication & $19(100 \%)$ \\
Impaired skin integrity & $19(100 \%)$ \\
Risk for infection & $19(100 \%)$ \\
Risk for falls & $19(100 \%)$ \\
Risk for bleeding & $19(100 \%)$ \\
Impaired comfort & $8(42 \%)$ \\
Nausea & $4(21 \%)$ \\
Anxiety & $2(10 \%)$ \\
Acute pain & $1(5 \%)$ \\
\hline
\end{tabular}

In relation to the actual nursing Diagnoses with their respective defining characteristics and related factors, there was a predominance of: impaired verbal communication characterized by difficulty in understanding the usual pattern of communication related to the anatomical defect - hearing $(\mathrm{n}=19 ; 100 \%)$, and impaired skin integrity related to disruption of the skin surface characterized by invasion of body structures and mechanical factors - surgery and intravenous catheter $(\mathrm{n}=19 ; 100 \%)$ (Table 2).

In relation to the nursing Diagnoses of risk with their respective risk factors, a predominance of the following was evidenced: risk of infection related to invasive procedures and inadequate primary defenses - ruptured skin and invasive procedures $(\mathrm{n}=19 ; 100 \%)$, risk for falls related to hearing difficulties and impaired balance $(\mathrm{n}=19 ; 100 \%)$ and risk of bleeding associated with treatment-related secondary effects - surgery $(\mathrm{n}=19 ; 100 \%)$ (Table 3$)$.
Table 2 - Actual Nursing Diagnoses with their respective defining characteristics and related factors - Bauru, SP, Brazil, 2016.

Actual Nursing Diagnoses n (\%)

\section{IMPAIRED VERBAL COMMUNICATION}

Defining characteristics

Difficulty in understanding the usual communication pattern

$19(100 \%)$

Related factors

Anatomical defect (hearing)

$19(100 \%)$

\section{IMPAIRED SKIN INTEGRITY}

Defining characteristics

Disruption of the skin surface

$19(100 \%)$

Invasion of body structures

$19(100 \%)$

Related factors

Mechanical factors (surgery, intravenous catheter)

$19(100 \%)$

IMPAIRED COMFORT

Defining characteristics

Crying

$8(42 \%)$

Restlessness

$3(16 \%)$

Irritability

$1(5 \%)$

Related factors

Secondary effects related to treatment (surgery)

$8(42 \%)$

NAUSEA

Defining characteristics

Vomiting sensation

$4(21 \%)$

Related factors

Mechanical factors (surgery)

$4(21 \%)$

ANXIETY

Defining characteristics

Irritability

$2(10 \%)$

Restlessness

$2(10 \%)$

Related factors

Change in health status

$2(10 \%)$

\section{ACUTE PAIN}

Defining characteristics

Observed evidence of pain

Facial expression

Related factors

Damaging agent (physical)

$1(5 \%)$

Regarding the main nursing interventions identified, we can highlight improvement in communication: auditory deficit, skin surveillance, protection against infection, prevention of falls, precautions against bleeding $(n=19 ; 100 \%)$, environment control: comfort $(n=8 ; 42 \%)$, nausea control $(n=4 ; 21 \%)$, reduction of anxiety $(n=2 ; 10 \%)$ and pain control $(\mathrm{n}=1 ; 5 \%)$ (Table 4$)$. 
Table 3 - Risk Nursing Diagnoses with their respective risk factors - Bauru, SP, Brazil, 2016.

\begin{tabular}{|c|c|}
\hline Risk Nursing Diagnoses & n (\%) \\
\hline \multicolumn{2}{|l|}{ RISK FOR INFECTION } \\
\hline \multicolumn{2}{|l|}{ Risk factors } \\
\hline Invasive Procedures & $19(100 \%)$ \\
\hline $\begin{array}{l}\text { Inadequate primary defenses (ruptured skin, invasive } \\
\text { procedures) }\end{array}$ & $19(100 \%)$ \\
\hline \multicolumn{2}{|l|}{ RISK FOR FALLS } \\
\hline \multicolumn{2}{|l|}{ Risk factors } \\
\hline Impaired balance & $19(100 \%)$ \\
\hline Hearing difficulties & $19(100 \%)$ \\
\hline \multicolumn{2}{|l|}{ RISK FOR BLEEDING } \\
\hline \multicolumn{2}{|l|}{ Risk factors } \\
\hline Secondary effects related to treatment (surgery) & $19(100 \%)$ \\
\hline \multicolumn{2}{|c|}{$\begin{array}{l}\text { Table } 4 \text { - Main nursing interventions in children in the immedi } \\
\text { ate postoperative period of cochlear implantation - Bauru, SP } \\
\text { Brazil, } 2016 \text {. }\end{array}$} \\
\hline Nursing Interventions & n (\%) \\
\hline Improvement in communication: auditory deficit & $19(100 \%)$ \\
\hline Skin surveillance & $19(100 \%)$ \\
\hline Protection against infection & $19(100 \%)$ \\
\hline Prevention of falls & $19(100 \%)$ \\
\hline Precautions against bleeding & $19(100 \%)$ \\
\hline Environment control: comfort & $8(42 \%)$ \\
\hline Nausea control & $4(21 \%)$ \\
\hline Reduction of anxiety & $2(10 \%)$ \\
\hline Pain control & $1(5 \%)$ \\
\hline
\end{tabular}

\section{DISCUSSION}

Regarding the socio-demographic characterization, males predominated, corroborating the literature that reports a prevalence of $\mathrm{AD}$ in this gender ${ }^{(5)}$. However, research showed that gender did not affect the development of oral language in children undergoing cochlear implants ${ }^{(13)}$.

The mean age was 3 years. In post-lingual patients, there is no time limit for CI. However, the longer the time of deafness, the worse the results will be for rehabilitating language and speech. On the other hand, CI has been advocated in prelingual patients prior to 2 years of age, meaning that the younger the patient is implanted, the better the results for language and speech rehabilitation. However, it must be emphasized that there is no age limit for $\mathrm{CI}^{(14-15)}$.

By listing the actual main nursing diagnoses and their respective interventions, in this order, we found a predominance of impaired verbal Communication with Improvement in communication: hearing deficit, and impaired skin Integrity with skin Surveillance.
The nursing Diagnosis of impaired verbal Communication implies a relevant factor, since communication within the nurse/patient/family relationship is considered to be fundamental for providing care that promotes well-being, in addition to performing nursing care systematization ${ }^{(16-18)}$.

From the moment the nursing Diagnosis of impaired verbal Communication is identified, nurses must begin planning care to minimize possible damage due to the communication deficit ${ }^{(1)}$. In turn, nursing interventions should facilitate the transmission of verbal and non-verbal messages.

For the most part, the strategies used by the professionals involve miming/gesturing during the consultation, since movement, gestural and facial expressions are perceived by sight, especially in the pediatric approach. Other methods include the use of signs, pictures, lip reading, and depending on the child's age, written communication ${ }^{(18-19)}$.

Another nursing Diagnosis identified in the present study consisted of impaired skin integrity, being described as altered epidermis and/or dermis ${ }^{(10)}$. This diagnosis is mainly related to mechanical factors, such as surgical incision ${ }^{(20)}$.

In this context, nursing interventions on patients in the immediate postoperative period should focus on preventing the formation of new lesions, in addition to promoting the repair of the affected tissue ${ }^{(21)}$.

The Nursing diagnosis of Risk for Infection is described as "increased susceptibility to invasion of pathogenic organisms", and it is commonly identified in patients who are in the postoperative period, mainly due to invasive procedures. The greater the number of procedures, the greater the risk. These include, but are not limited to, venous access, tissue destruction, and inadequate primary (ruptured) skin defenses caused by surgical trauma. Thus, nursing interventions include care with surgical incision and monitoring of invasive devices ${ }^{(20,22)}$.

In turn, the nursing Diagnosis of Risk for falls is defined as an increase in fall susceptibility, resulting in physical damage, being postoperatively prevalent due to the effects of anesthetic agents that cause drowsiness or possible behavior change, including agitation ${ }^{(20)}$.

Falls are the most commonly reported adverse events in the hospital environment, causing an increase in the incidence of trauma and hospitalization time. Children are more prone to falls ${ }^{(23)}$. It is worth mentioning that children with $\mathrm{AD}$ may present vestibular problems concomitant to hearing loss; among them, balance alterations along with manifestations that include falls, among others, impairing their daily activities ${ }^{(24)}$.

The planning of actions aimed at preventing falls should be based on the profile of the patient, including intrinsic and extrinsic factors. To minimize the risk for falls, professionals should dialogue with the patient, caregivers and family members, alerting them about the risk and its consequences $^{(23)}$. Other nursing interventions include Self-care assistance, Control of Urinary Elimination, Control of the Environment: safety, Area Restriction, Teaching: child safety, Exercise Therapy and Supervision: safety ${ }^{(11)}$.

The nursing diagnosis Risk for bleeding refers to the risk of loss of blood volume that can compromise homeostasis. Nursing Interventions are specifically based on Precautions 
against bleeding $^{(20)}$. CI patients in the postoperative period have hematomas among complications, which sometimes require drainage. However, in general they present satisfactory evolution ${ }^{(22)}$.

Other less frequent nursing Diagnoses in this study with their respective Interventions included: Impaired Comfort with Environmental Control: comfort; Nausea with Nausea Control, Anxiety with Anxiety Reduction, and Acute Pain with Pain Control.

The nursing Diagnoses impaired Comfort and Anxiety are similar. Both are related to the stress experienced by children in the perioperative period, especially in the immediate postoperative period in facing the unknown ${ }^{(25)}$.

Nursing care should be based on the ability to make the child fully understand what will happen, improving their degree of anxiety and discomfort. One way to improve these aspects is by establishing a relationship of trust with the child and their family in order to comprehensively elucidate for both of them the procedures to which the child will be submitted, providing a peaceful and comfortable environment ${ }^{(25)}$.

We emphasize that patients do not have access to the sound stimuli prior to activation of the CI. The activation of the device occurs in the late postoperative period, specifically 30 days after surgery ${ }^{(26)}$. However, a study showed that significant results were observed after 8 months of using the CI regarding auditory control related to voice production ${ }^{(27)}$.

Nausea is a common adverse event in the postoperative period, and it is more prevalent in children than adults. Prolonged surgical time, type of surgery such as otorhinolaryngology, use of volatile anesthetics and nitrous oxide have been identified as etiological factors for the occurrence of postoperative nausea and vomiting $(\mathrm{PONV})^{(28)}$.

Even in the perioperative period, some strategies for preventing nausea and vomiting can often minimize their postoperative incidence and promote faster and more peaceful rehabilitation. Hypovolemia and hyperoxygenation, as well as the use of inhalational anesthetics should be avoided. Prophylactic medications are recommended ${ }^{(28)}$.

Among the eligible Nursing Interventions, we can highlight Administration and Control of Medications, Nausea and Vomiting Control, Hydroelectrolyte Control, Diet Planning, Venous Puncture, Intravenous Therapy and Precautions against bronchoaspiration ${ }^{(11)}$.

In otologic surgeries, manipulation of structures related to balance control (vestibule and labyrinth) may lead to dizziness. In addition, the $\mathrm{CI}$ is inserted in the inner ear, more precisely in the cochlea, increasing the occurrence of $\mathrm{PONV}^{(26)}$.

The nursing Diagnosis of acute Pain refers to unpleasant sensory and emotional experience, being considered as the fifth vital sign. When confirmed, it should be a continuous focus of nurses' attention in order to increase the quality of care ${ }^{(29)}$.

In children who develop $\mathrm{AD}$ with consequent impaired verbal communication, pain will be expressed through nonverbal cues. Therefore, nurses and the team should be alert to non-verbal signs of pain, such as facial expressions and restlessness. In this context, we emphasize the importance of parental permanence during the postoperative period, considering that the parents have their own consolidated strategies of communication with the child.

In order to identify the nursing Diagnosis of acute Pain in Pediatrics, the nurse needs skills that include establishing an effective communication process with the child ${ }^{(25)}$.

Regarding the immediate postoperative period, the Acute pain nursing Diagnosis is not only related to the surgical wound, but also to the release of chemical mediators during the surgical procedure. Thus, the importance of evaluating pain is evident, and relating it to the vital signs of the patient, in addition to administering analgesics ${ }^{(20)}$.

Professionals responsible for patient care in the intraoperative period should be sensitized to the importance of pain relief and perform interventions for its treatment, minimizing its occurrence. However, records of patients' pain signs and/or complaints, as well as measures adopted to evaluate and control them are far from being ideal ${ }^{(21)}$.

It is inferred that the low incidence of nursing Diagnoses of acute Pain in the present study is related to the analgesia protocol used in the institution, where analgesics and antiinflammatories are administered at regular intervals and intercalated during intra and postoperative periods. However, it is important to emphasize the absence of implemented methodologies for evaluating postoperative pain, such as assessment scales; a fact that could somehow influence this result.

Finally, we emphasize that treatment through $\mathrm{CI}$ is a process that involves different steps, which include the diagnosis of AD. Other treatment modalities, for example, include the previous individual sound amplification apparatus, pre-implant evaluation, implant application, transoperative and postoperative auditory rehabilitation periods. Thus, the surgery should take place in qualified centers and by specialized professionals ${ }^{(14)}$.

Systematized nursing care contributes to minimizing postoperative complications in CI surgery, favoring success for auditory and linguistic rehabilitation, as well as the quality of life of these patients and their family members ${ }^{(30)}$.

\section{CONCLUSION}

The nursing Diagnoses and Interventions listed in the present study referring to the immediate postoperative period of CI were related to communication, bleeding control, surgical wound care, infection prevention, comfort and well-being. These guide the nursing team, favoring quality, humanized and holistic care grounded in evidence.

The fact that the present research was developed in a single center, despite it being a reference center, limits generalizing the results. Thus, multicenter studies are encouraged. Studies that evaluate cause and effect relationships are also necessary, including validation of the results related to the performed nursing interventions.

However, the contributions of this research made it possible to formalize a care profile of children in the postoperative situation of CI through identification of nursing Diagnoses and their respective defining characteristics, related or risk factors, enabling the planning of specific interventions directed to the real needs of patients and contributing to quality, safe and humanized care. 
RESUMO

Objetivo: Identificar os principais diagnósticos e intervenções de enfermagem em crianças submetidas a implante coclear em pósoperatório imediato. Método: Estudo transversal realizado entre fevereiro e abril de 2016. Foram considerados o histórico de enfermagem (anamnese e exame físico) e os diagnósticos de enfermagem (NANDA - Internacional) com suas respectivas intervenções (Nursing Intervention Classification - NIC). Para construção dos resultados utilizou-se da análise estatística descritiva. Resultados: Participaram do presente estudo 19 crianças. Os principais diagnósticos de enfermagem elencados foram: Comunicação verbal prejudicada, Integridade da pele prejudicada, Risco de infecção, Risco de queda e Risco de sangramento ( $n=19 ; 100 \%)$. Quanto às intervenções de enfermagem, prevaleceram: Melhora na comunicação: deficit auditivo, Supervisão da pele, Proteção contra infecção, Prevenção de quedas e Precauções contra sangramento $(\mathrm{n}=19 ; 100 \%)$. Conclusão: Os diagnósticos e as intervenções de enfermagem referentes ao pós-operatório de implante coclear relacionaram-se com comunicação, controle de sangramento, cuidados com a ferida operatória, prevenção de infecção, conforto e bem-estar.

\section{DESCRITORES}

Enfermagem Pediátrica; Implante Coclear; Perda Auditiva; Processos de Enfermagem; Diagnóstico de Enfermagem.

\section{RESUMEN}

Objetivo: Identificar los principales diagnósticos e intervenciones de enfermería en niños sometidos a implante coclear en el posoperatorio inmediato. Método: Estudio transversal realizado entre febrero y abril de 2016. Fueron considerados los antecedentes de enfermería (anamnesis y examen físico) y los diagnósticos de enfermería (NANDA - Internacional) con sus respectivas intervenciones (Nursing Intervention Classification - NIC). Para la construcción de los resultados se utilizó el análisis estadístico descriptivo. Resultados: Participaron en el presente estudio 19 niños. Los principales diagnósticos de enfermería enlistados fueron: Comunicación verbal perjudicada, Integridad de la piel perjudicada, Riesgo de infección, Riesgo de caída y Riesgo de sangrado (n=19; 100\%). En cuanto a las intervenciones de enfermería, prevalecieron: Mejora en la comunicación: déficit auditivo, Supervisión de la piel, Protección contra infección, Prevención de caídas y Precauciones contra sangrado ( $\mathrm{n}=19 ; 100 \%)$. Conclusión: Los diagnósticos y las intervenciones de enfermería referentes al posoperatorio de implante coclear se relacionaron con comunicación, control de sangrado, cuidados con la herida operatoria, prevención de infección, confort y bienestar.

\section{DESCRIPTORES}

Enfermería Pediátrica; Implantación Coclear; Pérdida Auditiva; Procesos de Enfermería. Diagnóstico de Enfermería.

\section{REFERENCES}

1. Silva MJP. Comunicação tem remédio: a comunicação nas relações interpessoais em saúde. 9a ed. São Paulo: Loyola; 2013.

2. Aurélio FS, Silva SP, Rodrigues LB, Kuniyoshi IC, Silva M, Botelho N. Satisfaction of patients fit with a hearing aid in a high complexity clinic. Braz J Otorhinolaryngol. 2012;78(5):69-77.

3. Ebrahimi H, Mohammadi E, Mohammadi MA, Pirzadeh A, Mahmoudi H, Ansari I. Stigma in mothers of deaf children. Iran J Otorhinolaryngol. 2015;27(79):109-18.

4. Timothy BK, Tolson D, Day T, McColgan G, Kroll T, Maclaren W. Older people's views on what they need to successfully adjust to life with a hearing aid. Health Soc Care Community. 2013; 21(3):293-302.

5. Brasil. Secretaria de Direitos Humanos da Presidência da República; Secretaria Nacional de Promoção dos Direitos da Pessoa com Deficiência, Coordenação-Geral do Sistema de Informações sobre a Pessoa com Deficiência. Cartilha do Censo 2010: Pessoas com Deficiência. Brasília: SDH-PR/SNPD; 2012.

6. Calhau CMDF, Lima Junior LRP, Reis AMCS, Capistrano AKB, Lima DVSP, Calhau ACDF, et al. Etiology profile of the patients implanted in the cochlear implant program. Braz J Otorhinolaryngol. 2011;77(1):13-8.

7. Vieira SS, Bevilacqua MC, Ferreira NMLA, Dupas G. Cochlear implant: the complexity involved in the decision making process by the family. Rev Latino Am Enfermagem. 2014;3(22):15-24.

8. Vieira SS, Bevilacqua MC, Ferreira NMLA, Dupas G. Discovery of hearing impairment by the family: seeing an idealized future collapse. Acta Paul Enferm. 2012;25(n.spe 2):82-8.

9. Conselho Federal de Enfermagem. Resolução COFEN n. 358, de 15 outubro 2009. Dispõe sobre a Sistematização da Assistência de Enfermagem e a implementação do Processo de Enfermagem em ambientes, públicos ou privados, em que ocorre o cuidado profissional de Enfermagem, e dá outras providências [Internet]. Brasília; 2009 [citado 2016 out. 10]. Disponível em: http://www.cofen.gov.br/resoluocofen-3582009_4384.html

10. NANDA International. Diagnósticos de Enfermagem da NANDA: definições e classificação 2012-2014. Porto Alegre: Artmed; 2012.

11. Dochterman JM, Bulechek GM. Classificação das Intervenções de Enfermagem (NIC). 6 a ed. Porto Alegre: Artmed; 2016.

12. Carvalho EC, Cruz DALM, Herdman TH. Contribuição das linguagens padronizadas para a produção do conhecimento, raciocínio clínico e prática clínica da Enfermagem. Rev Bras Enferm. 2013;66(n.esp):134-41.

13. Ramos D, Jorge JX, Teixeira A, Ribeiro C, Paiva A. Development of language skills in children with cochlear implants: does the gender have any influence? Rev CEFAC. 2015;17(2):535-41.

14. Hsu HW, Fang TJ, Lee LA, Tsou YT, Chen SH, Wu CM. Multidimensional evaluation of vocal quality in children with cochlear implants: a cross-sectional, case-controlled study. Clin Otolaryngol. 2014;39(1):32-8.

15. Calhau CMDF, Lima Junior LRP, Reis AMCS, Capistrano AKB, Lima DVSP, Calhau ACDF et al. Etiology profile of the patients implanted in the cochlear implant program. Braz J Otorhinolaryngol. 2011;77(1):13-8. 
16. Luciano TS, Nóbrega MML, Saparolli ECL, Barros ALBL. Cross mapping of nursing diagnoses in infant health using the International Classification of Nursing Practice. Rev Esc Enferm USP. 2014;48(2):247-53.

17. Fakhr-Movahedi A, Rahnavard Z, Salsali M, Negarandeh R. Exploring nurse's communicative role in nurse-patient relations: a qualitative study. J Caring Sci. 2016;5(4):267-76.

18. Oliveira YCA, Coura AS, Costa GMC, França ISX. Communication between health professionals-deaf people: an integrative review. J Nurs UFPE On line [Internet]. 2015 [cited 2016 Oct 10];9(2):957-64. Available from: http://www.revista.ufpe.br/revistaenfermagem/index.php/ revista/article/viewFile/5502/pdf_7317

19. Britto FR, Samperiz MMF. Communication difficulties and strategies used by the nurses and their team in caring for the hearing impaired. Einstein (São Paulo). 2010;8(1):80-5.

20. Souza TM, Carvalho R, Paldino CM. Diagnósticos, prognósticos e intervenções de enfermagem na sala de recuperação pós-anestésica. Rev SOBECC (São Paulo). 2012;17(4):33-47.

21. Bertoncello KCG, Savio B, Ferreira JM, Amante LN, Nascimento ERP. Nursing diagnoses and proposals for nursing interventions for patients in the immediate post-operative period following elective surgery. Cogitare Enferm. 2014;19(3):582-9.

22. Lima Junior LRP, Rodrigues Junior FA, Calhau CMD, Calhau ACDF, Palhano CTP. Postoperative complications in implanted patients in the Cochlear Implant Program of Rio Grande do Norte - Brazil. Braz J Otorhinolaryngol. 2010;76(4):517-21.

23. Clancy A, Mahler M. Nursing staffs' attentiveness to older adults falling in residential care: an interview study. J Clin Nurs. 2016;25(910):1405-15.

24. Rodrigues AT, Bertin V, Vitor LGV, Fujisawa DS. Crianças com e sem deficiência auditiva: o equilíbrio na fase escolar. Rev Bras Educ Esp. 2014;20(2):169-78.

25. Smeltzer SC, Bare BG. Brunner e Suddarth: tratado de enfermagem médico-cirúrgica. 13ª ed. Rio de Janeiro: Guanabara Koogan; 2016.

26. Bento RF, Lima Junior LRP, Tsuji RK, Gomez MVSG, Lima DVSP, Brito Neto RV. Tratado de implante coclear e próteses auditivas implantáveis. Rio de Janeiro: Thieme; 2014.

27. Jafari N, Izadi F, Salehi A, Dabirmoghaddam P, Yadegari F, Ebadi A, et al. Objective voice analysis of pediatric cochlear implant recipients and comparison with hearing aids users and hearing controls. J Voice [Internet]. 2016 [cited 2016 Oct 10]. Available from: http://www. sciencedirect.com/science/article/pii/S0892199716302880

28. Gondim CRN, Japiassú AM, Portari Filho PE, Almeida GF, Kalichsztein M, Nobre GF. Prevention and treatment of postoperative nausea and vomiting. Rev Bras Ter Intensiva. 2009;21(1):89-95.

29. Novaes ES, Torres MM, Oliva APV. Nursing diagnoses in surgical clinic. Acta Paul Enferm. 2015;1(28):26-31.

30. Hou JH, Zhao SP, Ning F, Rao SQ, Han DY. Postoperative complications in patients with cochlear implants and impacts of nursing intervention. Acta Otolaryngol. 2010;130(6):687-95. 